Article

\title{
Effect of Linseed (Linum usitatissimum) Mucilage and Chitosan Edible Coatings on Quality and Shelf-Life of Fresh-Cut Cantaloupe (Cucumis melo)
}

\author{
Mayra Z. Treviño-Garza ${ }^{1}$, Ruth C. Correa-Cerón ${ }^{1}$, Eugenia G. Ortiz-Lechuga ${ }^{1}$, \\ Karla K. Solís-Arévalo ${ }^{1}$, Sandra L. Castillo-Hernández ${ }^{2}{ }^{1}$, Claudia T. Gallardo-Rivera ${ }^{2}$ and \\ Katiushka Arévalo Niño ${ }^{1, *}$ \\ 1 Facultad de Ciencias Biológicas, Instituto de Biotecnología, Universidad Autónoma de Nuevo León, \\ Av. Pedro de Alba s/n, Cd. Universitaria, C.P. 66455 San Nicolás de los Garza, N.L., Mexico; \\ mayra_trevinogarza@hotmail.com (M.Z.T.-G.); ruthcoceron92@gmail.com (R.C.C.-C.); \\ bioeugenica@hotmail.com (E.G.O.-L.); kasolisa@hotmail.com (K.K.S.-A.) \\ 2 Facultad de Ciencias Biológicas, Departamento de Alimentos, Universidad Autónoma de Nuevo León, \\ Av. Pedro de Alba s/n, Cd. Universitaria, C.P. 66455 San Nicolás de los Garza, N.L., Mexico; \\ sandra.castilloh@uanl.mx (S.L.C.-H.); claudia.gallardorv@uanl.edu.mx (C.T.G.-R.) \\ * Correspondence: katiushka.arevalonn@uanl.edu.mx; Tel.: +52-81-8329-4000 (ext. 6492)
}

Received: 11 May 2019; Accepted: 3 June 2019; Published: 5 June 2019

\begin{abstract}
We have evaluated the effect of edible coatings (ECs) based on linseed mucilage (LM), chitosan $(\mathrm{CH})$, and their combination $(\mathrm{LMCH})$ on the quality and shelf life of fresh-cut cantaloupe. Cantaloupe was washed, sanitized, and processed (peeled, seeded, and cut) and then coated by immersion, packed, and stored for 18 days at $4{ }^{\circ} \mathrm{C}$. The ECs were effective at reducing the juice leakage and softening of the product. The $\mathrm{EC}$ based on $\mathrm{CH}$ was the most effective at preserving the color parameter and reducing the general microbiological growth. However, the LMCH combination decreased the antimicrobial effect of chitosan against microorganisms. Also, $\mathrm{CH}$ and LM ECs helped preserve the overall sensory characteristics, increasing the acceptance to 12-15 days. Finally, the $\mathrm{LMCH}$ combination helped preserve the characteristics of color and odor; however, it modified the texture and taste of fresh-cut cantaloupe and its sensory acceptance was similar to the control (up to 9 days).
\end{abstract}

Keywords: linseed mucilage; fresh-cut fruit; cantaloupe; quality; shelf life

\section{Introduction}

The present-day accelerated lifestyle has increased the production and consumption of minimally processed horticultural and ready-to-eat products [1-3]. However, the development of fresh-cut products from fruits such as pineapple, papaya, watermelon, mango, and cantaloupe, among others, has been limited because these foods are highly perishable compared to intact fruit. Also, processing operations, such as disinfection, washing, drying, cutting, and packaging, can cause alterations in physical integrity (e.g., mechanical damage of fruit tissue) and product safety (e.g., microbial cross-contamination), leading to a series of changes related to microbial susceptibility and physicochemical and sensory stability, which decrease overall quality and shelf life [4-6].

Cantaloupe is one of the most popular fresh-cut fruits on the market and is consumed worldwide [7-10]. Cantaloupe is characterized by its aroma, intense flavor [11], and dietary fiber content, as well as its vitamin (A, B, and C), calcium, potassium, iron, and $\beta$-carotene levels $[8,12-14]$. However, fresh-cut cantaloupe has a short shelf life (up to 9 days) because the processing and storage of the product trigger changes in physical integrity, loss of juice, softening of the pulp, enzymatic 
browning and darkening, alteration in organic acid and soluble solid content, degradation of ascorbic acid, production of ethylene, accumulation of ethanol and acetaldehyde [11], development of spoilage microorganisms, and changes in aroma and flavor, which are determinants of quality [6].

Some of the methods used to improve the quality and increase the shelf life of cantaloupe products include packaging in modified atmospheres [15], treatment with ozone [16], ultraviolet light $[7,17,18]$, gamma radiation [19], and edible coatings (ECs). ECs are considered safe and effective for the conservation of highly perishable products [3].

The use of polysaccharide-based ECs has been successful at reducing some problems associated with the loss of quality (physicochemical, microbiological, or sensory) and shelf life of fresh-cut cantaloupe due to its mechanical and barrier properties, as well as the incorporation of some active ingredients [20,21]. Among the most important materials used for this purpose are chitosan (CH), alginate, pectin [8,9,12-14,22-24], gellan [22], carboxymethylcellulose [25], and, recently, Aloe vera [5].

$\mathrm{CH}$ is a linear cationic polymer comprised of units of $D$-glucosamine and $N$-acetyl- $D$-glucosamine and is characterized by its antimicrobial properties (against fungi, bacteria, and viruses), low toxicity, biodegradability, biocompatibility, and low cost [26]. This polysaccharide has been effective as an EC in fresh cut-fruit, such as papaya [27], kiwi [28], and cantaloupe $[6,9,10]$. On the other hand, linseed mucilage (LM) is a heteropolymer composed of a mixture of acidic (rhamnogalacturonan) and neutral (arabinoxylan) polysaccharides, which comprises approximately $8 \%$ of the weight of linseed (Linum usitatissimum) and is characterized as a highly viscous, colorless liquid with good water retention properties $[29,30]$. Because of these properties, LM can be used as a dietary fiber, thickening agent, foaming agent, emulsifier, stabilizer, and as a drug delivery system, among other applications [31]. Interestingly, LM has been explored little as an EC in fresh-cut fruit $[3,32,33]$. Thus, we hereby aimed to determine the effect of LM and CH ECs and their combination ( $\mathrm{LMCH}$ ) on quality parameters and shelf life of fresh-cut cantaloupe.

\section{Materials and Methods}

\subsection{Materials}

Linseed and cantaloupe were purchased at a local market (Mercado de Abastos Estrella, San Nicolas de los Garza, Mexico). Cantaloupe was selected based on the following characteristics: uniform size, color and characteristic odor, absence of physical damage, no evidence of fungal infection, and with a soluble solids content between $8-10$ degrees Brix $\left({ }^{\circ} \mathrm{Bx}\right)$ [8]. Crab shell $\mathrm{CH}$ ( $85 \%$ deacetylation) was acquired from Sigma-Aldrich (St. Louis, MO, USA) and glycerol (99.5\%) from Jalmek Científica S.A. de C.V. (San Nicolas de los Garza, Mexico).

\subsection{Mucilage Extraction Process}

Linseeds were placed in distilled water $(30 \% w / v)$ and kept under constant agitation $(2 \mathrm{~h})$ until a viscous solution was formed. Subsequently, the seeds were removed using a strainer and precipitation of mucilage was made by adding two volumes of ethanol $\left(2: 1\right.$, Jalmek $\left.96^{\circ}\right)$ to the solution. Precipitated mucilage was recovered using a strainer and dried in a muffle $\left(70{ }^{\circ} \mathrm{C}\right.$ for $\left.24 \mathrm{~h}\right)$, pulverized mechanically to obtain a fine powder, and stored until later use [32].

\subsection{Development and Application of Coating-Forming Solutions}

Three different treatments were evaluated: (a) LM: $2.0 \%$ linseed mucilage and $0.5 \%$ glycerol; (b) $\mathrm{CH}: 1.0 \%$ chitosan, $1.0 \%$ acetic acid, and $0.5 \%$ glycerol; and (c) LMCH: $1.0 \%$ linseed mucilage, $0.5 \%$ chitosan, $0.5 \%$ acetic acid, and $0.5 \%$ glycerol. Cantaloupe was washed with potable water and sanitized in a solution of sodium hypochlorite $\left(250 \mathrm{mg} \mathrm{kg}^{-1}\right)$ for $1 \mathrm{~min}$, then peeled, seeded, cut into $2 \mathrm{~cm}$-sided cubes and laid (immersed) in the different coating-forming solutions for $2 \mathrm{~min}$. Coated cantaloupe pieces were allowed to drain (to remove the coating solution excess) and dried for 20 min inside a laminar airflow cabinet. Pieces of fresh-cut cantaloupe without coating were used as control. Finally, 
cantaloupe pieces were packaged $(800 \mathrm{~g})$ in polyethylene terephthalate containers with lids (capacity of $32 \mathrm{oz} / 946 \mathrm{~mL}$ ) and stored under refrigeration $\left(4^{\circ} \mathrm{C}\right.$ to $\left.90 \% \mathrm{RH}\right)$ for a period of 18 days $[8,13,22]$.

\subsection{Analysis of Quality and Shelf Life of the Product}

Evaluations for coated and uncoated fresh-cut cantaloupe were performed on days $0,3,6,9,12$, 15 , and 18 of storage at $4{ }^{\circ} \mathrm{C}$.

\subsubsection{Microbiological Quality Analysis}

Fresh-cut cantaloupe (10 g) was weighed (three replicates for each treatment) and placed in sterile bags (Nasco Whirl-Pak $\left.{ }^{\circledR}, 18 \mathrm{oz} / 532 \mathrm{~mL}\right)$. Subsequently, $90 \mathrm{~mL}$ of sterile peptone water $(0.85 \% \mathrm{NaCl}$ and $0.1 \%$ peptone) were added to the bags and contents were homogenized mechanically ( $1 \mathrm{~min}$ ). Then, for microbial counts, serial dilutions were made and aliquots of $1 \mathrm{~mL}$ of each dilution were inoculated in sterile Petri dishes [27,34]. For total aerobic counts (aerobic mesophilic microorganisms), plate count agar (Difco ${ }^{\mathrm{TM}}, 20 \mathrm{~mL}$ per plate) was used, and samples were incubated at $35 \pm 2{ }^{\circ} \mathrm{C}$ for $48 \mathrm{~h}$. Moreover, for mold and yeast counts, potato dextrose agar (BD Bioxon ${ }^{\circledR} 20 \mathrm{~mL}$ per plate) was used, and the samples were incubated at $25 \pm 2{ }^{\circ} \mathrm{C}$ for 5 days [6,9]. Finally, after incubation, the colonies were counted, and results were expressed as colony-forming units per gram $\left(\mathrm{CFU} \mathrm{g}{ }^{-1}\right)$.

\subsubsection{Physicochemical Quality Analysis}

- Juice Leakage, Firmness, and Color

Juice leakage of fresh-cut cantaloupe (10 replicas per treatment) was determined based on the weight of the product throughout the storage time using an analytical balance (Mettler Toledo PG4002-S, Columbus, $\mathrm{OH}, \mathrm{USA})$, according to the following equation: weight loss $(\%)=$ (initial weight of the fruit) - (final weight of the fruit)/(initial weight of the fruit) $\times 100[8,12]$. For firmness evaluations of the fruit (five replicas per treatment), a digital penetrometer (Extech model FHT200, Waltham, MA, USA) equipped with a $3 \mathrm{~mm}$ tip was used; the results were expressed in newtons (N). Finally, the color analysis was carried out with a digital colorimeter (Blue-HP200, Bluemetric, S.A. de C.V., Monterrey, Mexico), and the results were expressed based on the color coordinates $L^{*}$ (luminosity), $a^{*}$ (green-red), and $b^{*}$ (yellow-blue) [8]. In addition, overall color difference $(\Delta E)$ was calculated according to the following formula: $\Delta E^{*}=\left[\left(L-L_{0}\right)^{2}+\left(a-a_{0}\right)^{2}+\left(b-b_{0}\right)^{2}\right]^{1 / 2}$ [3], where, $L_{0}, a_{0}$ and $b_{0}$ are the initial color measurements (day 0 ), and $L, a$ and $b$ represent the color measurements at a specific day.

- $\mathrm{pH}$, Titratable Acidity, Total Soluble Solids, and Ascorbic Acid Determinations

Fresh-cut cantaloupe for the different treatments was homogenized in a food processor and used for chemical determinations. $\mathrm{pH}$ determination was carried out using a previously calibrated $\mathrm{pH}$ meter (Beckman, model 390; Method 981.12, AOAC, Brea, CA, USA) [35]. Total acidity (TA) was determined by titration with sodium hydroxide solution $(0.1 \mathrm{~N})$ based on the method reported by Chong et al. [9] and the results were expressed as grams of malic acid per $100 \mathrm{~g}$ of sample. Total soluble solids content (TSS) was determined using a hand-held refractometer (Extech model RF15) and expressed using the ${ }^{\circ} \mathrm{Bx}$ scale (Method 932.14, AOAC) [35]. Finally, ascorbic acid content (AA) was determined by titration with iodine (Hycel de México, S.A. de C.V., Zapopan, Mexico; $0.1 \mathrm{~N}$ ) based on previous reports [36], and results were expressed as milligrams per $100 \mathrm{~g}$ of sample. Determinations were conducted in triplicate $(n=3)$.

\subsubsection{Sensory Quality Analysis}

Sensory evaluations were carried out to determine the acceptance of coated fresh-cut cantaloupe by consumers. The sensory panel was made up of students and staff of our college's Biotechnology Institute $(n=10)$ who frequently consume this product. Color, odor, flavor, texture, and general acceptance were evaluated according to the following scale: $1=$ dislike extremely, $2=$ dislike, $3=$ neither 
like nor dislike, $4=$ like, and $5=$ like very much; these parameters were decisive for the determination of quality and shelf life of fresh-cut cantaloupe (scores $\geq 2.5$ were considered acceptable) $[8,13]$. Finally, the presence of molds and yeasts, as well as the visual damage caused by these microorganisms on the product surface (decay rate), was determined based on the following scale: $1=$ undamaged fruit $(0 \%), 2=$ slightly damaged fruit (up to $25 \%), 3=$ moderately damaged fruit $(26 \%-50 \%), 4=$ severely damaged fruit $(51 \%-75 \%)$, and $5=$ extremely damaged fruit $(76 \%-100 \%)$. Decay rate scores $\leq 1.0$ were considered acceptable [37].

\subsection{Statistical Analysis}

Statistical differences between the treatments were determined by one-way analysis of variance (ANOVA) and Tukey test using SPSS 20.0 software. $p$ values $\leq 0.05$ were considered statistically significant.

\section{Results and Discussion}

\subsection{Microbiological Quality Testing}

The development of spoilage microorganisms during the shelf life of fresh-cut cantaloupe is shown in Figure 1. In relation to aerobic mesophilic microorganisms, initial counts (day 0) were significantly $(p<0.05)$ higher in the control fruit $\left(3.52 \pm 0.01 \log\right.$ CFU g $\left.{ }^{-1}\right)$ compared to LMCH$\left(2.32 \pm 0.05 \log \mathrm{CFU} \mathrm{g}^{-1}\right), \mathrm{LM}-$, and $\mathrm{CH}$-coated samples $\left(<1.00 \log \mathrm{CFU} \mathrm{g}^{-1}\right)$. During storage, a gradual increase $(p<0.05)$ was observed in the microbial levels of all treatments. However, by day 18 , this increase was significantly higher $(p<0.05)$ in the control fruit $\left(7.75 \pm 0.10 \log \mathrm{CFU} \mathrm{g}{ }^{-1}\right)$, followed by the LM- and LMCH-coated samples, whose microbial growth was very similar $(p>0.05)$ between days 12 and 18 of storage (ranging from 5.81 to $7.30 \log$ CFU g ${ }^{-1}$ ). Finally, by the end of the storage time, fruit treated with $\mathrm{CH}$ presented the lowest microbial counts $\left(5.68 \pm 0.01 \log \mathrm{CFU} \mathrm{g}^{-1}\right.$, Figure 1A).

In contrast, the presence of mold and yeasts was not detected between days 0 and 6 of storage in fruit coated with $\mathrm{CH}$ and $\mathrm{LMCH}\left(<1.00 \log \mathrm{CFU} \mathrm{g}{ }^{-1}\right)$, while the fruit coated with $\mathrm{LM}$ and the control presented microbial levels that fluctuated between 1.01 and $1.21 \log C F U ~ g^{-1}$. During days 9 to 18 of storage, a significant increase $(p<0.05)$ was detected in the mold and yeast counts of all treatments. $\mathrm{CH}$ EC was the most effective at reducing the growth of these microorganisms (1.05-1.39 log CFU g $\left.{ }^{-1}\right)$, followed by LMCH and LM ECs, whose microbial levels fluctuated between 1.04-1.88 CFU g ${ }^{-1}$ and 1.37-2.04 CFU g ${ }^{-1}$ between days 9 and 18 of storage, respectively. Finally, the highest counts were recorded on uncoated fresh-cut cantaloupe, with microbial counts of 1.68-3.26 $\log$ CFU g ${ }^{-1}$ (days 9 to 18, Figure 1B).

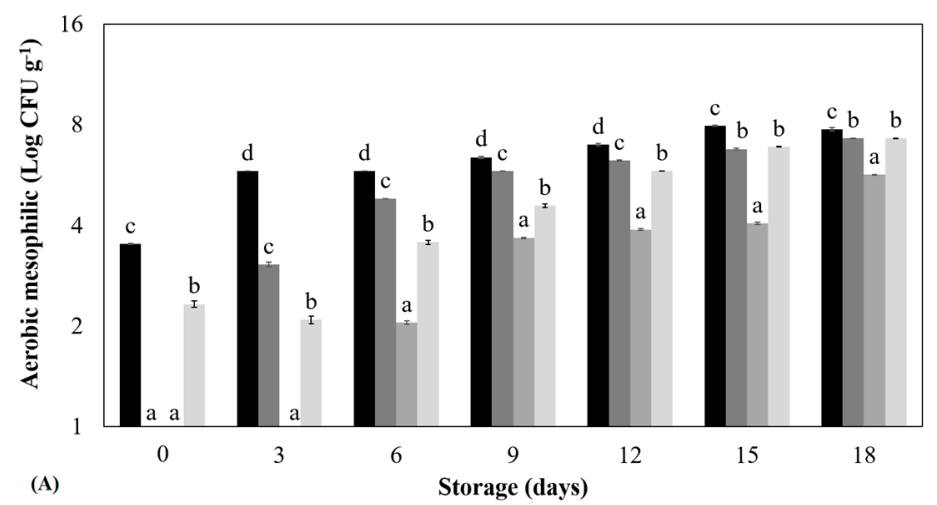

Figure 1. Cont. 


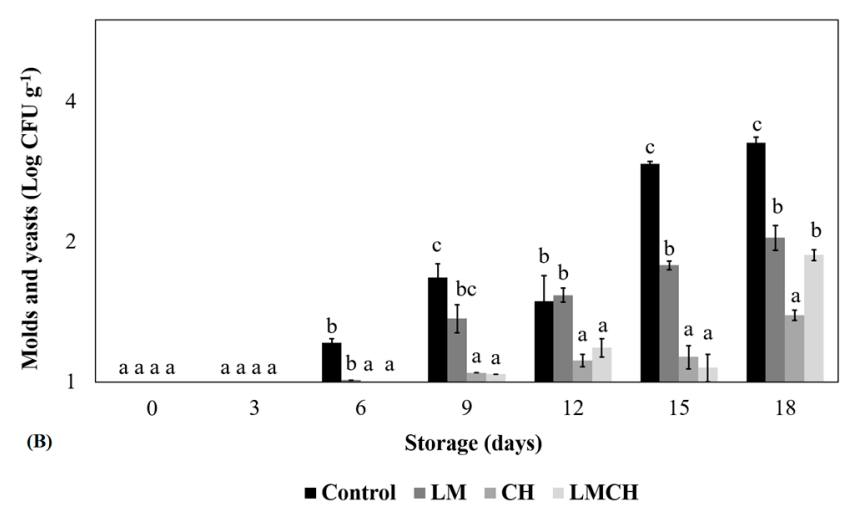

Figure 1. Growth of (A) aerobic mesophilic microorganisms (total aerobic counts) and (B) molds and yeasts in fresh-cut cantaloupe with and without an edible coating (control) during 18 days of storage at $4{ }^{\circ} \mathrm{C}$. Means which do not have a common letter $(\mathrm{a}, \mathrm{b}, \mathrm{c})$ are significantly different $(p \leq 0.05)$. Vertical bars represent \pm SD. LM: linseed mucilage; $\mathrm{CH}$ : chitosan; LMCH: linseed mucilage + chitosan.

In general, the ECs based on LM were able to reduce the growth of molds and yeasts, which is similar to the finding of Yousuf et al. [3] in pomegranate arils. Moreover, it has been proposed that the effectiveness of ECs based on $\mathrm{CH}[8,9,13,14,25]$ can be attributed to the positive charge of the protonated amino group $\left(\mathrm{NH}_{3}{ }^{+}\right)$present in the $\mathrm{C}-2$ of the polysaccharide; this group has the ability to interact with phosphoryl groups present in the cell membrane, altering the cellular permeability and causing leakage of proteinaceous and other intracellular components $[9,26]$. The EC based on $\mathrm{LMCH}$ was not as effective at reducing the microbial levels when compared to the $\mathrm{CH} \mathrm{EC}$; this effect can be attributed to an electrostatic interaction between these polymers (polyelectrolytes with opposite charges), which can reduce the antimicrobial activity of $\mathrm{CH}$. Similar results have been reported by Poverenov et al. [14] with ECs based on CH/alginate in fresh-cut cantaloupe and Treviño et al. [32] with ECs based on $\mathrm{CH}$ and mucilages of cactus, linseed, and Aloe vera in fresh-cut pineapple.

\subsection{Juice Leakage, Firmness, and Color Tests}

Table 1 shows the juice leakage of fresh-cut cantaloupe. Juice leakage values on day 3 of storage fluctuated between $0.28 \%$ and $0.56 \%$, with no significant differences $(p>0.05)$ among treatments. Between days 6 and 18 of storage, a significant increase was found in all treatments; however, this increase was most evident in the control fruit $(2.64 \%-5.12 \%)$; on the other hand, we detected no significant differences ( $p>0.05)$ among fresh-cut cantaloupe coated with $\mathrm{LM}, \mathrm{CH}$, and $\mathrm{LMCH}$, with leakage values of between $3.32 \%$ and $3.78 \%$ by day 18 of storage. Our results are consistent with those of Chong et al. [9], who worked with ECs based on $\mathrm{CH} / \mathrm{CaCl}_{2}$ in fresh-cut honeydew melon. In contrast, Yousuf et al. [3] reported higher values for this parameter with EC based on linseed mucilage/lemongrass essential oil in ready-to-eat pomegranate arils.

Additionally, the application of ECs significantly increased $(p<0.05)$ the firmness of LM-coated cantaloupe from 19.20 to $28.32 \mathrm{~N}$ (day 0; Table 1). During storage time, a decrease in firmness "tissue softening" was observed in LM-, LMCH-coated, and control samples, without significant differences $(p>0.05)$ between days 3 and 18. Nonetheless, coated cantaloupe pieces showed slightly higher firmness values compared to control samples (Table 1). In addition, the fluctuations found in firmness values between the different days of evaluation could be related to the inherent variability of the fruit. On the other hand, $\mathrm{CH}$-coated fruit presented the highest and stable firmness values during the total storage time $(p<0.05$; Table 1$)$. A similar effect has been reported in previous studies $[24,25,37]$. Compared to previous studies, lower firmness values have been reported on fresh-cut cantaloupe coated with pectin [23], cellulose [38], carboxymethylcellulose [25], and alginate [24]. Conversely, higher values have been reported using multilayered ECs with the formula $\mathrm{CH} /$ pectin/trans-cinnamaldehyde [8]. 
Table 1. Physical properties of fresh-cut cantaloupe with and without EC (control) during 18 days of storage at $4{ }^{\circ} \mathrm{C}$.

\begin{tabular}{|c|c|c|c|c|}
\hline Storage (Days) & Control & $\mathbf{L M}$ & $\mathrm{CH}$ & LMCH \\
\hline \multicolumn{5}{|c|}{ Juice Leakage (\%) } \\
\hline 3 & $\mathrm{~A}_{0.56(0.07)^{\mathrm{f}}}$ & $\mathrm{A}_{0.45(0.13)^{\mathrm{f}}}$ & $\mathrm{A}_{0.28}(0.04)^{\mathrm{d}, \mathrm{e}}$ & $\mathrm{A}_{0.34}(0.16)^{\mathrm{d}, \mathrm{e}}$ \\
\hline 6 & $\mathrm{C}_{2.64(0.07)} \mathrm{e}$ & ${ }^{\mathrm{B}} 1.44(0.27)^{\mathrm{e}}$ & ${ }^{A} 0.83(0.13)^{d}$ & 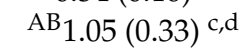 \\
\hline 9 & $C_{3.98(0.12)} d$ & ${ }^{B} 2.83(0.24)^{d}$ & $\mathrm{~A}_{2.14(0.38)^{\mathrm{C}}}$ & $\mathrm{A} 1.97(0.13)^{\mathrm{b}, \mathrm{c}}$ \\
\hline 12 & ${ }^{\mathrm{B}} 4.33(0.22)^{\mathrm{C}}$ & $\mathrm{A}_{3.13(0.22)^{\mathrm{C}}}$ & $\mathrm{A}_{2.59}(0.23)^{\mathrm{b}, \mathrm{c}}$ & 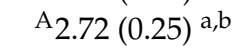 \\
\hline 15 & ${ }^{\mathrm{B}} 4.74(0.11)^{\mathrm{b}}$ & $\mathrm{A}_{3.43(0.34)^{\mathrm{b}}}$ & 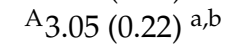 & $\mathrm{A}_{3.33(0.33)^{\mathrm{a}}}$ \\
\hline 18 & ${ }^{B} 5.12(0.15)^{a}$ & A $3.78(0.29)^{a}$ & $\mathrm{~A}_{3.32(0.25)^{\mathrm{a}}}$ & $\mathrm{A}_{3.53(0.69)^{\mathrm{a}}}$ \\
\hline \multicolumn{5}{|c|}{ Firmness (N) } \\
\hline 0 & $\mathrm{~A}_{19.20(0.13) \mathrm{b}, \mathrm{c}}$ & 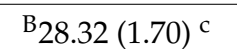 & $\mathrm{A}, \mathrm{B} 21.97(2.00)^{\mathrm{a}}$ & $\mathrm{A}_{20.67(1.42)}{ }^{\mathrm{a}, \mathrm{b}}$ \\
\hline 3 & $\mathrm{~A}_{23.57(2.24)^{\mathrm{C}}}$ & $\mathrm{A}_{25.80(0.72) \mathrm{b}, \mathrm{c}}$ & $\mathrm{A}_{27.85(3.51)^{\mathrm{a}}}$ & $\mathrm{A}_{22.42(2.35)^{\mathrm{b}}}$ \\
\hline 6 & $\mathrm{~A}_{15.15(1.02)^{\mathrm{a}, \mathrm{b}}}$ & $\mathrm{A}_{16.63(1.77)^{\mathrm{a}}}$ & ${ }^{\mathrm{A}} 19.73(1.21)^{\mathrm{a}}$ & ${ }^{\mathrm{A}} 18.42(1.44)^{\mathrm{a}, \mathrm{b}}$ \\
\hline 9 & $\mathrm{~A}_{10.90(0.96)^{\mathrm{a}}}$ & $\mathrm{AB}_{13.92(1.58)^{\mathrm{a}}}$ & ${ }^{\mathrm{B}} 21.23(2.69)^{\mathrm{a}}$ & $\mathrm{A}, \mathrm{B} 14.20(1.25)^{\mathrm{a}, \mathrm{b}}$ \\
\hline 12 & $\mathrm{~A}_{14.23(1.13)^{\mathrm{a}, \mathrm{b}}}$ & $\mathrm{A}_{18.91(2.71)^{\mathrm{a}, \mathrm{b}}}$ & $\mathrm{A}_{21.13(1.08)^{\mathrm{a}}}$ & $\mathrm{A} 12.72(2.11)^{\mathrm{a}}$ \\
\hline 15 & $\mathrm{~A}_{10.40(0.19)^{\mathrm{a}}}$ & ${ }^{\mathrm{B}} 17.32(0.59)^{\mathrm{a}, \mathrm{b}}$ & $\mathrm{A}, \mathrm{B} 16.20(2.02)^{\mathrm{a}}$ & $\mathrm{A}, \mathrm{B} 14.48(1.04)^{\mathrm{a}, \mathrm{b}}$ \\
\hline 18 & $\mathrm{~A}_{14.05(0.79)^{\mathrm{a}, \mathrm{b}}}$ & $\mathrm{A}_{15.12(0.65)^{\mathrm{a}}}$ & $\mathrm{B}_{23.09(1.31)^{\mathrm{a}}}$ & $\mathrm{A}_{13.78(1.67)^{\mathrm{a}, \mathrm{b}}}$ \\
\hline
\end{tabular}

Note: Values within a column (lowercase) or row (uppercase) which do not have a common letter are significantly different $(p \leq 0.05)$. The values in parentheses indicate \pm standard deviation. $\mathrm{EC}=$ edible coating, $\mathrm{LM}=$ linseed mucilage, and $\mathrm{CH}=$ chitosan.

In general, the changes found during the shelf life of fresh-cut cantaloupe regarding parameters of juice leakage and firmness are associated with the superficial evaporation of water due to respiration and transpiration processes $[9,23]$. Also, microbial growth and enzymatic degradation of cellular polysaccharides (e.g., pectin) can produce pulp softening [14,25]. Application of semipermeable polymeric ECs on the surface of the pieces of cantaloupe provides improved structural integrity and helps control gas diffusion, moisture loss (Table 1), and microbial growth [38] (Figure 1).

Application of ECs did not change $(p>0.05)$ initial parameters (day 0$)$ of color in fresh-cut cantaloupe; luminosity ( $L^{*}$ ) fluctuated between 50.57 and 55.38, the $a^{*}$ coordinate (redness) presented values of $14.15-15.24$, and the $b^{*}$ coordinate (yellowness) fluctuated between 38.40 and 41.87 (Figure 2A-C). Regarding the $L^{*}$ parameter (Figure 2A), the values remained constant during storage and although no significant effect was found $(p>0.05)$, by day 18 , the coated cantaloupe pieces presented slightly higher luminosity values (50.79-55.61) compared to the control group (47.78 \pm 4.11$)$. Conversely, between days 9 and 18 of storage, there was a significant decrease $(p<0.05)$ in the values of $a^{*}$ in all treatments, but without significant difference $(p>0.05)$ among the cantaloupe pieces coated with LMCH and LM and the control (days 0-18; 13.42-6.61, 14.40-4.90, and 13.13-5.78, respectively; Figure 2B). In addition, the fresh-cut cantaloupe pieces coated with $\mathrm{CH}$ showed the highest $a^{*}$ values (days $0-18 ; 14.40-9.32)$. On the other hand, after day 9 , a significant decrease $(p<0.05)$ was also found in the values of the $b^{*}$ coordinate in all treatments. Nevertheless, by the end of storage, the CH EC was more effective at maintaining the $b^{*}$ values $(24.75 \pm 1.95)$ relative to $\mathrm{LMCH}, \mathrm{LM}$, and the control, whose values fluctuated between 19.47 and 21.23 (Figure 2C). 


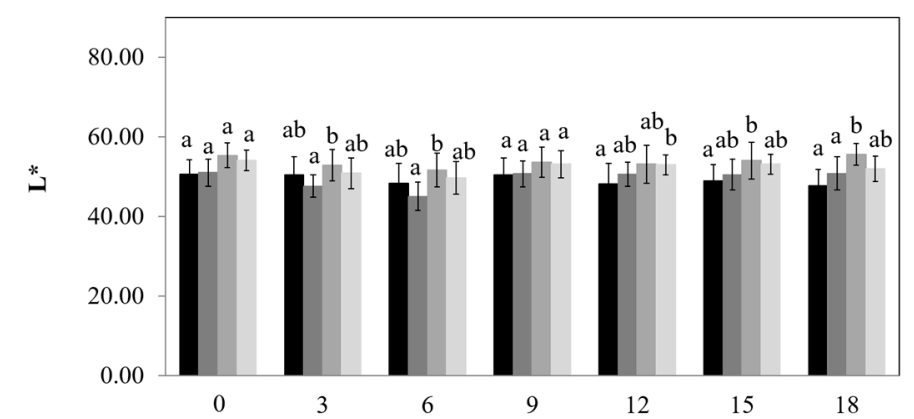

(A)

Storage (days)

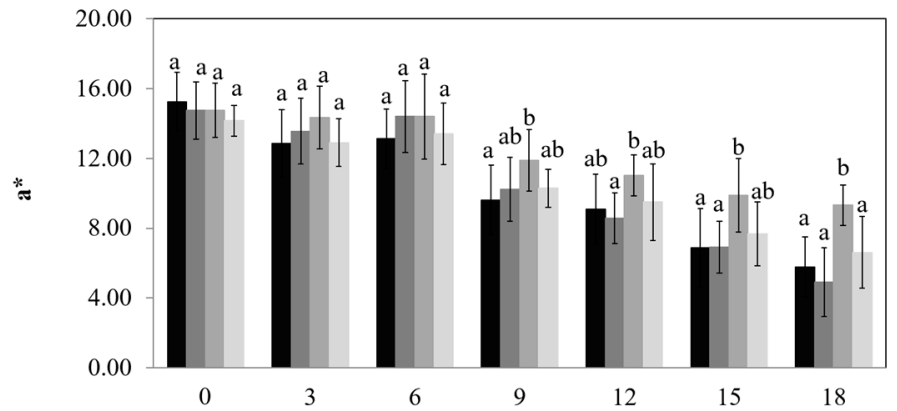

(B)

Storage (days)
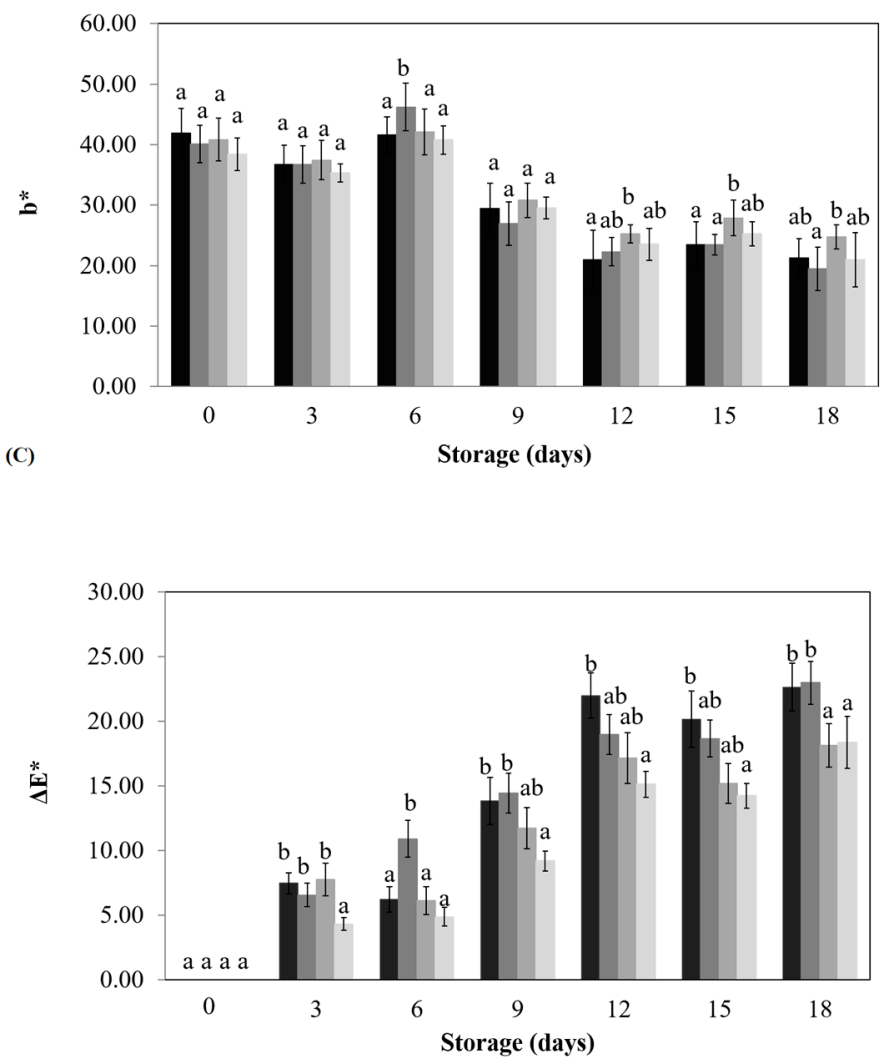

(D)

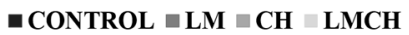

Figure 2. Color attributes-(A) $L^{*},(\mathbf{B}) a^{*},(\mathbf{C}) b^{*}$, and (D) $\Delta E^{*}$-of fresh-cut cantaloupe with and without an edible coating (control) during 18 days of storage at $4{ }^{\circ} \mathrm{C}$. Means which do not have a common letter $(\mathrm{a}, \mathrm{b}, \mathrm{c})$ are significantly different $(p \leq 0.05)$. Vertical bars represent \pm SD. 
In general, after 18 days of storage (Figure 2D), ECs elaborated with $\mathrm{CH}$ and $\mathrm{LMCH}$ were the most effective at reducing $(p<0.05)$ the changes in the color $(\Delta E=18.13$ and 18.34 , respectively) and in preserving the yellow-orange color compared to LM and control $(\Delta E=22.97$ and $\Delta E=22.63$, respectively); these parameters are indicators of a reduction of oxidative (e.g., oxidizable phenol compounds) and enzymatic browning (e.g., polyphenol oxidase activity) $[8,9,13,24]$ and also are associated with symptoms of translucency (dark and glassy pulp) in the fresh-cut cantaloupe [39,40]. These results are consistent with those found in our sensory color evaluations (Figure 3a).

(a)

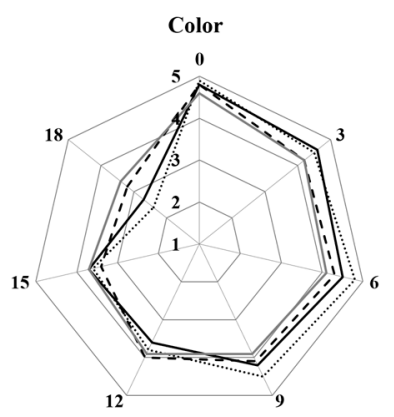

(c)

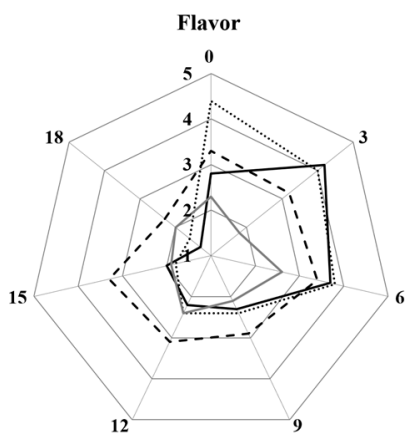

- Control

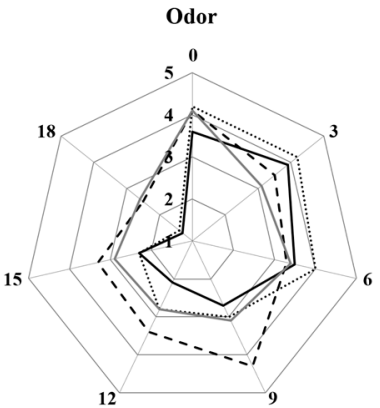

(b)

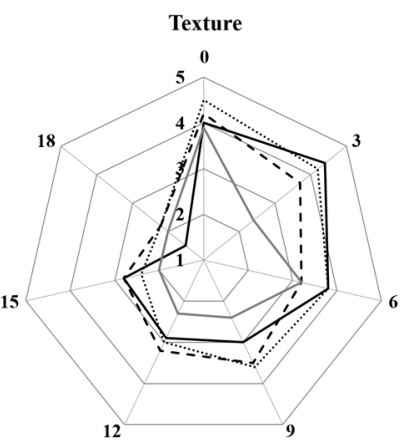

(d)

- LMCH

Figure 3. Sensory quality parameters-(a) color, (b) odor, (c) flavor, and (d) texture-of fresh-cut cantaloupe with and without an edible coating (control) during 18 days of storage at $4{ }^{\circ} \mathrm{C}$.

$\mathrm{pH}, \mathrm{TA}, \mathrm{TSS}$, and AA Content

Regarding physicochemical analysis, the application of ECs decreased $(p<0.05)$ the $\mathrm{pH}$ of fresh-cut cantaloupe (day 0, Table 2). The low $\mathrm{pH}$ values in the fruit coated with $\mathrm{CH}(5.99 \pm 0.01)$ and $\mathrm{LMCH}$ $(5.72 \pm 0.01)$ can be attributed to the $\mathrm{pH}$ of the solutions forming the coating $(\mathrm{CH}, 3.62 \pm 0.01 ; \mathrm{LMCH}$, $3.93 \pm 0.01$, data not shown), which contained acetic acid for the dissolution of $\mathrm{CH}$. According to the reports of Martiñon et al. [8] and Chong et al. [9], the reduction in $\mathrm{pH}$ values can have a beneficial effect in reducing the early development of spoilage microorganisms, which is in agreement with the results found in our microbiological analysis (Figure 1). Moreover, the LM EC presented pH values similar to the control fruit, which is consistent with the findings of Yousuf et al. [3] in pomegranate arils. Between days 6 and 18, there was a decrease $(p<0.05)$ in the $\mathrm{pH}$ values of all treatments; the lowest values were presented by the fruit treated with $\mathrm{LMCH}(4.33 \pm 0.02)$, followed by the control, LM, and CH (5.38-5.57, Table 2), which is in line with previous studies [3,5,8,41]. Changes in this parameter during storage can be attributed to the accumulation of organic acids characteristic of the metabolism of fresh-cut cantaloupe [9,41,42]. 
Table 2. Chemical properties of fresh-cut cantaloupe with and without EC (control), during 18 days of storage at $4{ }^{\circ} \mathrm{C}$.

\begin{tabular}{|c|c|c|c|c|}
\hline Storage (Days) & Control & $\mathbf{L M}$ & $\mathbf{C H}$ & LMCH \\
\hline \multicolumn{5}{|c|}{$\mathrm{pH}$} \\
\hline 0 & $\mathrm{D}_{6.79(0.02) \mathrm{d}}$ & $c_{6.68(0.03)}{ }^{d}$ & $\mathrm{~B}_{5.99(0.01) \mathrm{d}, \mathrm{e}}$ & $\mathrm{A}_{5.72(0.01)^{\mathrm{f}}}$ \\
\hline 3 & ${ }^{\mathrm{A}} 6.12(0.02)^{\mathrm{C}}$ & ${ }^{B} 6.34(0.09)^{c}$ & ${ }^{\mathrm{A}} 6.10(0.01)^{\mathrm{e}}$ & ${ }^{\mathrm{A}} 6.00(0.01)^{\mathrm{e}}$ \\
\hline 6 & $\mathrm{~B}_{5.68}(0.03)^{b}$ & $\mathrm{~A}_{5.53(0.01)^{\mathrm{b}}}$ & $\mathrm{C}_{5.78(0.00)^{\mathrm{c}, \mathrm{d}}}$ & $\mathrm{A}_{5.56(0.00)^{d}}$ \\
\hline 9 & $\mathrm{D}_{5.52(0.03)^{\mathrm{a}, \mathrm{b}}}$ & $C_{5.47(0.01)^{a, b}}$ & ${ }^{B} 5.65(0.01) b, c$ & ${ }^{\mathrm{A}} 4.98(0.00)^{\mathrm{c}}$ \\
\hline 12 & $\mathrm{~B}_{5.53(0.04)} \mathrm{a}, \mathrm{b}$ & ${ }^{B} 5.53(0.03)^{b}$ & $\mathrm{~B}_{5.40(0.19)^{\mathrm{a}}}$ & $\mathrm{A}_{4.53(0.02)^{\mathrm{b}}}$ \\
\hline 15 & $C_{5.58(0.03)} b$ & $\mathrm{~B}_{5.40(0.04)^{\mathrm{a}}}$ & ${ }^{\mathrm{B}} 5.42(0.01)^{\mathrm{a}, \mathrm{b}}$ & $\mathrm{A}_{4.35(0.04)^{\mathrm{a}}}$ \\
\hline 18 & $\mathrm{C}_{5.38(0.14)^{\mathrm{a}}}$ & ${ }^{B} 5.53(0.05)^{b}$ & $\mathrm{~B}_{5.57}(0.10)^{\mathrm{a}, \mathrm{b}, \mathrm{c}}$ & $\mathrm{A}_{4.33(0.02)^{\mathrm{a}}}$ \\
\hline \multicolumn{5}{|c|}{ TA (Malic Acid, g $100 \mathrm{~g}^{-1}$ ) } \\
\hline 0 & $\mathrm{~A}_{0.026(0.00)^{\mathrm{a}}}$ & $\mathrm{A}_{0.034}(0.01)^{\mathrm{a}}$ & $c_{0.103(0.00) b, c}$ & ${ }^{\mathrm{B}} 0.073(0.00)^{\mathrm{a}}$ \\
\hline 3 & ${ }^{\mathrm{A}} 0.064(0.01)^{\mathrm{a}}$ & $\mathrm{A}_{0.073(0.00)^{\mathrm{a}}}$ & ${ }^{\mathrm{B}} 0.107(0.00)^{b, c}$ & ${ }^{\mathrm{B}} 0.115(0.01)^{\mathrm{b}}$ \\
\hline 6 & ${ }^{\mathrm{B}} 0.265(0.00)^{\mathrm{d}}$ & ${ }^{B} 0.282(0.12) d$ & ${ }^{A} 0.188(0.00)^{d}$ & ${ }^{A} 0.158(0.01)^{c}$ \\
\hline 9 & ${ }^{\mathrm{B}} 0.213(0.00)^{\mathrm{C}}$ & ${ }^{\mathrm{B}} 0.218(0.01)^{\mathrm{c}}$ & $\mathrm{A}_{0.179(0.01)^{\mathrm{d}}}$ & $\mathrm{C}_{0.269(0.01)^{\mathrm{e}}}$ \\
\hline 12 & ${ }^{\mathrm{B}} 0.162(0.01)^{\mathrm{b}}$ & ${ }^{\mathrm{B}} 0.171(0.00)^{\mathrm{b}}$ & ${ }^{\mathrm{A}} 0.128(0.01)^{\mathrm{C}}$ & $\mathrm{C}_{0.265(0.00)^{\mathrm{e}}}$ \\
\hline 15 & ${ }^{\mathrm{A}} 0.068(0.00)^{\mathrm{a}}$ & ${ }^{\mathrm{B}} 0.145(0.00)^{\mathrm{b}}$ & ${ }^{\mathrm{A}} 0.077(0.01)^{\mathrm{a}, \mathrm{b}}$ & $\mathrm{C}_{0.205(0.01)^{\mathrm{d}}}$ \\
\hline 18 & $\mathrm{~A}_{0.055(0.00)^{\mathrm{a}}}$ & ${ }^{\mathrm{A}} 0.043(0.01)^{\mathrm{a}}$ & ${ }^{\mathrm{A}} 0.059(0.01)^{\mathrm{a}}$ & ${ }^{\mathrm{B}} 0.205(0.01)^{\mathrm{d}}$ \\
\hline \multicolumn{5}{|c|}{$\mathrm{TSS}\left({ }^{\circ} \mathrm{Bx}\right)$} \\
\hline 0 & $\mathrm{C}_{9.00(0.00)^{b}}$ & A8.00 $(0.00)^{c}$ & $\mathrm{D}_{10.0(0.00)^{\mathrm{d}}}$ & ${ }^{B} 8.30(0.17)^{b}$ \\
\hline 3 & B9.00 (0.00) b & ${ }^{A} 8.10(0.05)^{c}$ & ${ }^{B} 9.33(0.06)^{c}$ & ${ }^{B} 9.00(0.00)^{c}$ \\
\hline 6 & B $8.90(0.10)^{b}$ & $\mathrm{~A}_{8.00(0.00)^{\mathrm{C}}}$ & $\mathrm{A}_{8.10(0.10)^{\mathrm{b}}}$ & A $8.07(0.06)^{b}$ \\
\hline 9 & ${ }^{\mathrm{A}} 8.10(0.06)^{\mathrm{a}}$ & ${ }^{A} 8.03(0.05)^{c}$ & ${ }^{A} 8.17(0.06)^{b}$ & ${ }^{B} 9.13(0.06)^{c}$ \\
\hline 12 & $\mathrm{C}_{8.90(0.11)^{\mathrm{b}}}$ & ${ }^{A} 8.03(0.06)^{c}$ & ${ }^{\mathrm{B}} 8.27(0.10)^{\mathrm{b}}$ & $\mathrm{D}_{9.17(0.06)^{\mathrm{c}}}$ \\
\hline 15 & ${ }^{\mathrm{B}} 8.00(0.00)^{\mathrm{a}}$ & $\mathrm{A}_{7.03(0.06)^{\mathrm{b}}}$ & ${ }^{\mathrm{B}} 8.03(0.06)^{\mathrm{b}}$ & ${ }^{\mathrm{A}} 7.20(0.17)^{\mathrm{a}}$ \\
\hline 18 & $\mathrm{C}_{8.00(0.00)^{\mathrm{a}}}$ & ${ }^{\mathrm{A}} 6.47(0.25)^{\mathrm{a}}$ & ${ }^{\mathrm{B}} 7.10(0.06)^{\mathrm{a}}$ & B $7.27(0.06)^{a}$ \\
\hline \multicolumn{5}{|c|}{ AA $\left(m g 100 g^{-1}\right)$} \\
\hline 0 & $\mathrm{~A}_{10.09}(1.03)^{\mathrm{c}}$ & $\mathrm{A}_{10.68(1.78)^{\mathrm{b}}}$ & $\mathrm{A}, \mathrm{B} 13.05(1.03)^{\mathrm{c}}$ & $\mathrm{B}_{14.83(1.03)^{\mathrm{b}}}$ \\
\hline 3 & $\mathrm{~A}, \mathrm{~B} 9.49(1.03)^{\mathrm{C}}$ & ${ }^{\mathrm{B}} 10.68(0.10)^{\mathrm{b}}$ & ${ }^{\mathrm{B}} 11.27(1.03) \mathrm{b}, \mathrm{c}$ & $\mathrm{A}_{7.71(1.03)^{\mathrm{a}}}$ \\
\hline 6 & A $8.31(1.03)^{b, c}$ & ${ }^{\mathrm{A}} 6.53(1.03)^{\mathrm{a}}$ & A $7.12(1.03)^{a}$ & A8.31 (1.03) \\
\hline 9 & ${ }^{A} 6.53(1.03)^{a, b}$ & $\mathrm{~A}_{7.12(1.09)^{\mathrm{a}}}$ & ${ }^{A} 8.31(1.03)^{b}$ & ${ }^{\mathrm{A}} 6.53(1.03)^{\mathrm{a}}$ \\
\hline 12 & $\mathrm{~A}, \mathrm{~B} 6.53(1.03) \mathrm{a}, \mathrm{b}$ & $\mathrm{B}_{5.34(0.10)^{\mathrm{a}}}$ & $\mathrm{B} 7.71(1.03)^{\mathrm{a}}$ & $\mathrm{A}, \mathrm{B} 7.12(1.03)^{\mathrm{a}}$ \\
\hline 15 & $\mathrm{~A}_{6.53(1.03)^{\mathrm{a}, \mathrm{b}}}$ & ${ }^{A} 6.53(1.03)^{a}$ & ${ }^{A} 6.53(1.03)^{a}$ & $\mathrm{~A}_{5.93(1.03)^{\mathrm{a}}}$ \\
\hline 18 & $\mathrm{~A}_{4.75(1.03)^{\mathrm{a}}}$ & $\mathrm{A}_{5.93(1.03)^{\mathrm{a}}}$ & $\mathrm{A}_{5.93(1.03)^{\mathrm{a}}}$ & $\mathrm{A}_{5.93(1.03)^{\mathrm{a}}}$ \\
\hline
\end{tabular}

Note: Values within a column (lowercase) or row (uppercase) which do not have a common letter are significantly different $(p \leq 0.05)$. The values in parentheses indicate standard deviation. EC = edible coating, LM = linseed mucilage, $\mathrm{CH}=$ chitosan, $\mathrm{TA}=$ titratable acidity, $\mathrm{TSS}=$ total soluble solids, and AA = ascorbic acid.

Secondly, initial TA was higher in fresh-cut cantaloupe coated with $\mathrm{LMCH}$ and $\mathrm{CH}(0.073-0.103 \mathrm{mg}$

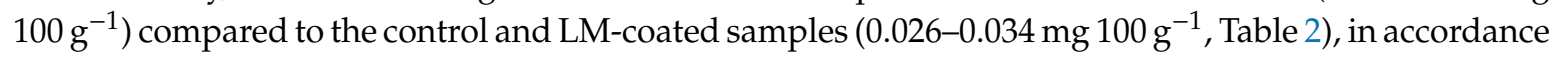
with $\mathrm{pH}$ values. Between days 6 and 12 of storage, an increase was observed $(p<0.05)$ in the TA of all treatments, followed by a decrease $(p<0.05)$ between days 15 and 18 . As reported by Lamikanra et al. [42], this effect can be related with the loss of malic acid and the production of lactic acid due to the microbial growth (malolactic fermentation). In addition, the highest TA values observed in the fresh-cut cantaloupe coated with LMCH during the whole trial period also can be accounted for by the low $\mathrm{pH}$ values attributed to the addition of acetic acid in the $\mathrm{CH}$-based coating-forming solutions $[13,28]$.

The initial TSS content fluctuated between 9.00 and $10.00{ }^{\circ} \mathrm{Bx}$, which is similar to the values reported in previous studies $[8,13,41]$. During the storage period, there was a decrease $(p<0.05)$ in TSS content in all treatments; this can be associated with the use of sugars as a nutrient (fermentation) during the growth of spoilage microorganisms [42]. However, by day 18 , the control samples had 
higher TSS values $\left(8.00 \pm 0.00^{\circ} \mathrm{Bx}\right)$ than the coated fruit, whose values fluctuated between 6.47 and $7.27^{\circ} \mathrm{Bx}$ (Table 2) $[9,40]$. This effect might be associated with a higher rate of water loss $[5,41]$ in accordance with our juice leakage evaluations (Table 1). Furthermore, the high content of TSS can also be an indicator of increased maturity in the control fruit [13,38].

Finally, initial AA content was higher $(p<0.05)$ for $\mathrm{CH}$ - and LMCH-coated samples $(13.05-14.83 \mathrm{mg}$ $\left.100 \mathrm{~g}^{-1}\right)$, followed by those coated with LM and the control $(p>0.05)$, whose values fluctuated between

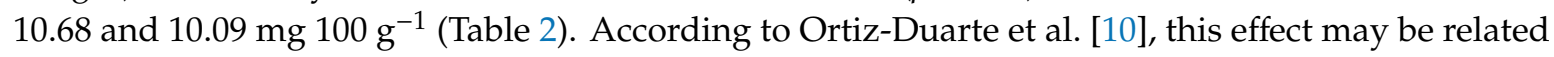
to the oxidation of AA after rind removal and during fruit processing; the application of $\mathrm{CH}$-based coatings on the surface of the cantaloupe slices helped reduce the exposure to the external environment, thus also reducing the initial loss of ascorbic acid (day 0). However, throughout storage, a gradual decrease of AA was observed in all treatments, without significant difference $(p>0.05)$ between the coated and control fruit by day 18 of storage (4.75-5.93 $\left.\mathrm{mg} 100 \mathrm{~g}^{-1}\right)$. Similar results were reported with multilayer ECs (CH/pectin/ $\mathrm{CaCl}_{2} /$ trans-cinnamaldehyde) in fresh-cut cantaloupe [8].

\subsection{Sensory Quality Testing}

The application of ECs did not change the initial parameters (day 0 ) of color, odor, texture, and decay rate, and there was no significant difference $(p>0.05)$ between the control and coated fruit for the different parameters evaluated (Figures 3 and 4 ), which is in agreement with previous reports $[3,8]$. On the contrary, the application of the ECs significantly influenced $(p<0.05)$ the initial parameters of flavor and overall acceptance. In the flavor parameter, the LM- and $\mathrm{CH}$-coated samples presented higher evaluations (4.40 and 3.30, respectively) than the control fruit ( $2.80 \pm 1.03)$, while the LMCH-coated samples presented the lowest evaluations because the panelists did not detect the characteristic flavor of the melon, and they referred to a "different" and unpleasant flavor in the product $(2.30 \pm 0.50)$. Therefore, the initial overall acceptance was lower for the LMCH-treated fruit ( $3.18 \pm 0.32)$, followed by the control $(3.24 \pm 0.24)$ and fruit treated with $\mathrm{LM}$ and $\mathrm{CH}$, which were the most frequently accepted by the panelists (scores of 3.48 and 3.86, respectively).

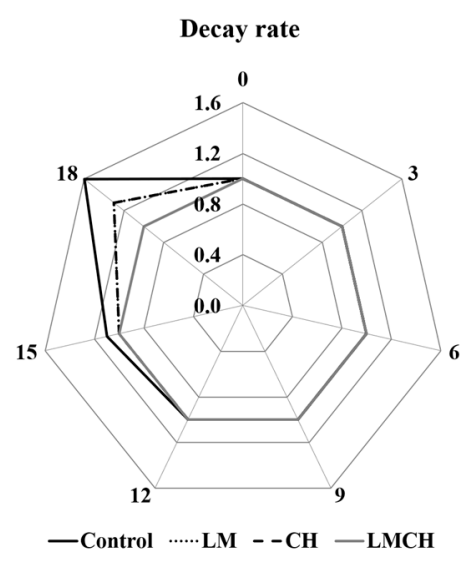

Figure 4. Decay rate of fresh-cut cantaloupe with and without an edible coating (control) during 18 days of storage at $4{ }^{\circ} \mathrm{C}$.

Regarding evaluations performed during storage time, a decrease of color scores was observed in all treatments, with significant differences $(p<0.05)$ between days 15 and 18 (Figure 3a). CH- and LMCH-coated fruit presented the highest scores ( $p<0.05,3.40-3.20$ and 3.40-3.70), while LM-coated samples and controls presented similar values without significant differences on days 15 and 18 ( $p>0.05,3.60-2.40$ and 3.70-2.70, respectively). As mentioned above, the appearance of fresh-cut cantaloupe might be affected by the translucency phenomenon $[22,39,43]$, which is characterized by a "glassy" appearance and darkening of color, changes in texture, and early maturity (associated with an increase in sugar content). These results are consistent with those obtained in our color, firmness, 
and TSS analyses (Figure 2, and Tables 1 and 2, respectively), and are characteristic of a senescence process [22]. The protection barrier provided by the ECs $(\mathrm{CH}$ and $\mathrm{LMCH})$ on the surface of the product was able to reduce the perceptible changes in color, attributed mainly to the phenomenon of translucency.

Secondly, a decrease $(p<0.05)$ was found in the odor values during storage time in all treatments. However, a significant preference was found $(p<0.05)$ with respect to the fruit coated with $\mathrm{CH}$ (4.30-2.50) and LMCH (3.10-2.60) between days 9 and 18 relative to the fruit treated with LM (3.00-1.40) and the control (2.70-1.30, Figure 3b). Undesirable changes in the aroma of fresh-cut cantaloupe might be associated with variations in the concentration of volatile compounds specific to fruit metabolism (e.g., acetate and nonacetate esters, aldehydes, and sulfur-containing compounds) [11,38], coupled with unpleasant "fermented" odors associated with microbial spoilage. These results are consistent with the findings of our microbial analysis (Figure 1) and agree with the findings of Martiñón et al. [8].

On the other hand, during storage, a significant decrease $(p<0.05)$ was found in the flavor evaluations for control and LM-coated fresh-cut cantaloupe, which presented acceptable scores $(\geq 2.5)$ until day 6 and 9, respectively (Figure 3c). Also, $\mathrm{CH}$-coated fruit presented acceptable flavor scores until day $15(3.30 \pm 0.45)$. On the contrary, $\mathrm{LMCH}$-coated samples had unacceptable scores $(<2.5)$, since this coating modified the typical and characteristic flavor of the cantaloupe. Changes in taste are related to the generation of volatile compounds (e.g., acetaldehyde, ethanol, and ethyl acetate, among others) [13,35], as well as the decrease in sugar content and organic acids (which contribute to sweetness and pleasant taste; Table 2) [39,40,42], and with microbial spoilage [20]. In general, the ECs were effective at reducing the microbial levels (Figure 1), thereby helping to prevent the development of unpleasant flavors during the shelf life of the product.

Regarding the texture parameter (Figure 3d), the scores decreased significantly $(p<0.05)$ during storage in all treatments, as was evidenced in the firmness analysis (Table 1). Changes in texture were most evident at days 12-15 for LM- and $\mathrm{CH}$-coated fruit and the control group, whose values were within the acceptable range (scores $\geq 2.5$ ). On the contrary, from day 3, LMCH-coated cantaloupe presented lower evaluations relative to the other treatments $(3.20 \pm 0.45$, Figure $3 d)$, with acceptable scores only until day $9(2.50 \pm 0.25)$. This was because the panelists detected the presence of the coating, similarly to previous reports $[8,13]$. However, in the firmness evaluations (Table 1 ), we found that LMCH-coated fruit was significantly firmer $(p<0.05)$ than the control group. This effect might be related to the adhesion of the coating to the melon surface [14]. According to previous reports, the electrostatic deposition technique (layer by layer) can be used as an alternative approach to improve the adhesion of the polysaccharides with opposite charges on the fruit surface [14,32].

The decay rate remained stable during storage for all treatments (1.00-1.10; Figure 4). By day 18, the coated fruit had low decay rate scores (1.00-1.30), without apparent damage to the surface of the fresh-cut cantaloupe. On the contrary, the control fruit showed signs of damage $(1.60 \pm 0.22,<25 \%)$ and the presence of mold and yeasts on the surface. These results are consistent with the findings of our microbial analysis (Figure 1b).

For the overall sensory acceptance, due to its organoleptic characteristics, $\mathrm{CH}$ - and LM-coated fresh-cut cantaloupe was accepted for 12-15 days (Figures 5 and 6). Also, although LMCH-coated samples helped to preserve the properties of color, odor, texture, and decay rate, the overall sensory acceptance was similar to the control fruit (up to 9 days) due to the change in flavor detected by the panelists (Figures 3, 5 and 6).

Our findings regarding the shelf life of fresh-cut cantaloupe are similar to those reported by Moreira et al. [13] (15 days with multilayer ECs based on $\mathrm{CH} /$ pectin/ $\mathrm{CaCl}_{2} /$ trans-cinnamaldehyde), Ferrari et al. [23] (14 days with ECs based on pectin/calcium lactate), and Chong et al. [9] (13 days with ECs based on $\mathrm{CH} /$ calcium chloride), but were higher than those reported by Haffez et al. [25] (8 days with ECs based on $\mathrm{CH} /$ carboxymethylcellulose/calcium chloride) and Martiñón et al. [8] (9 days with ECs based on $\mathrm{CH} /$ pectin/ $\mathrm{CaCl}_{2} /$ trans-cinnamaldehyde). 


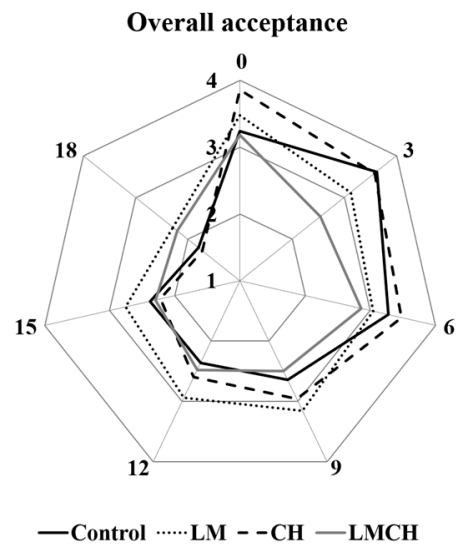

Figure 5. Overall sensory acceptance of fresh-cut cantaloupe with and without an edible coating (control) during 18 days of storage at $4{ }^{\circ} \mathrm{C}$.

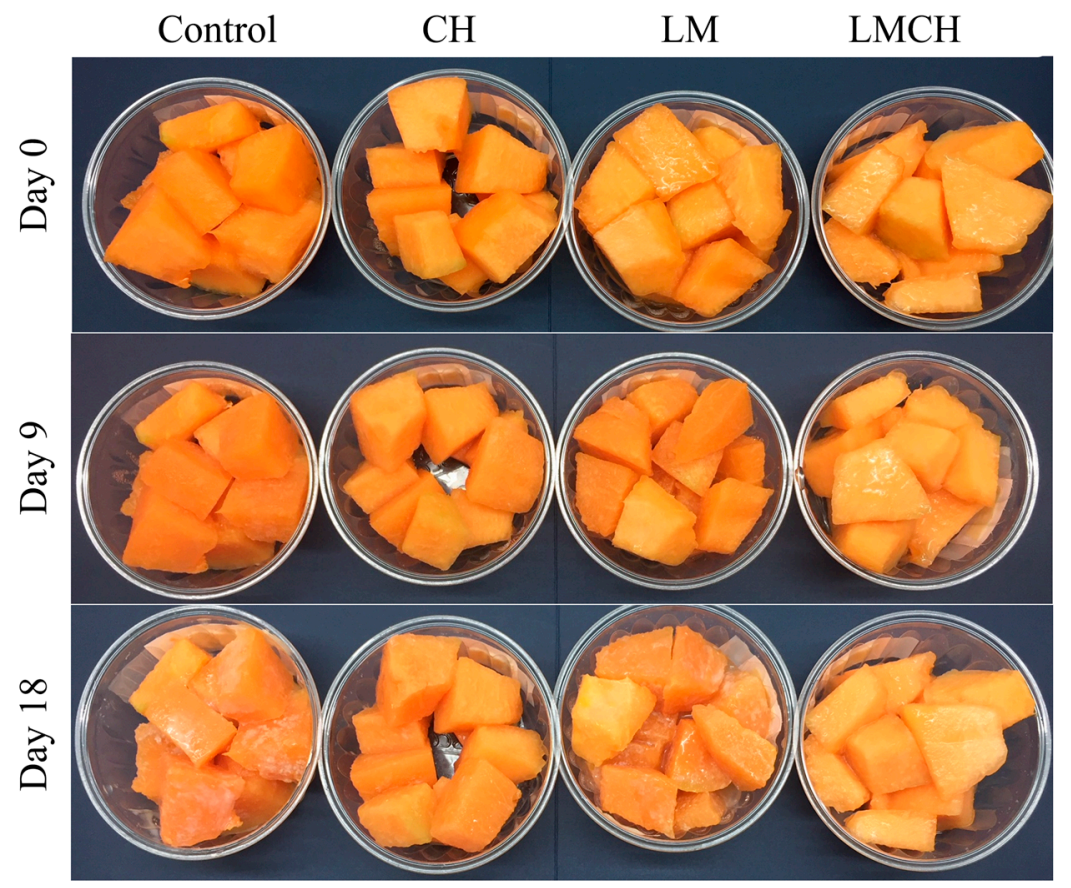

Figure 6. Appearance of fresh-cut cantaloupe with and without an edible coating (control) after 0, 9, and 18 days of storage at $4{ }^{\circ} \mathrm{C}$.

\section{Conclusions}

ECs based on $\mathrm{LM}, \mathrm{CH}$, and their combination $(\mathrm{LMCH})$ were effective at reducing juice leakage and fruit softening. The $\mathrm{CH}$ EC was the most effective at preserving the color parameters $\left(a^{*}\right.$ and $\left.b^{*}\right)$, while LM and LMCH had only a slight effect on preserving the luminosity $\left(L^{*}\right)$. ECs based on $\mathrm{CH}$ $(\mathrm{CH}$ and $\mathrm{LMCH})$ decreased the $\mathrm{pH}$ and increased TA. However, LM did not help to preserve the AA content. Moreover, the ECs helped to reduce the growth of aerobic mesophilic microorganism, molds, and yeasts. The EC based on $\mathrm{LMCH}$ was less effective at reducing the overall microbial levels relative to $\mathrm{CH}$; this finding might be associated with an electrostatic interaction between these polymers. The antimicrobial effect of the ECs was reflected in a reduction of the sensory decay rate. The $\mathrm{CH}$ and LM ECs helped to preserve the overall sensory characteristics (color, odor, flavor, and texture), thereby increasing the acceptance of the fresh-cut cantaloupe to 12-15 days. Finally, the combination approach $(\mathrm{LMCH})$ helped to preserve the color and odor properties. However, the overall sensory acceptance of 
the $\mathrm{LMCH}$-coated cantaloupe was similar to the control (up to 9 days) because this EC modified the texture and flavor of the fresh-cut fruit.

Author Contributions: Conceptualization, K.A.N. and M.Z.T.-G.; Methodology, M.Z.T.-G., R.C.C.-C., and K.K.S.-A.; Formal Analysis, M.Z.T.-G., and K.A.N.; Investigation, M.Z.T.-G., R.C.C.-C., E.G.O.-L., K.K.S.-A., C.T.G.-R., S.L.C.-H., and K.A.N.; Resources, K.A.N.; Data Curation, M.Z.T.-G., R.C.C.-C., and K.K.S.-A.; Writing-Original Draft Preparation, M.Z.T.-G., R.C.C.-C., and E.G.O.-L.; Writing-Review and Editing, K.A.N.; Visualization, M.Z.T.-G., R.C.C.-C., and K.A.N.; Supervision, K.A.N.; Funding Acquisition, K.A.N.

Funding: This research was funded by Program of Support for Research, Science and Technology, PAICYT, UANL, IT461-15.

Conflicts of Interest: The authors declare no conflict of interest.

\section{References}

1. Vodnar, D.C.; Pop, O.L.; Dulf, F.V.; Socaciu, C. Antimicrobial efficiency of edible films in food industry. Not. Bot. Horti Agrobot. Cluj-Napoca 2015, 43, 302-312. [CrossRef]

2. Oms-Oliu, G.; Rojas-Grau, M.A.; González, L.A.; Varela, P.; Soliva-Fortuny, R.; Hernando, M.I.; Munuera, I.P.; Fiszman, S.; Martin-Belloso, O. Recent approaches using chemical treatments to preserve quality of fresh-cut fruit: A review. Postharvest Biol. Technol. 2010, 57, 139-148. [CrossRef]

3. Yousuf, B.; Kumar, S.A. Flaxseed gum in combination with lemongrass essential oil as aneffective edible coating for ready-to-eat pomegranate arils. Int. J. Biol. Macromol. 2017, 104, 1030-1038. [CrossRef] [PubMed]

4. Raybaudi-Massilia, R.M.; Mosqueda-Melgar, J.; Martín-Belloso, O. Edible alginate-based coating as carrier of antimicrobials to improve shelf life and safety of fresh-cut melon. Int. J. Food Microbiol. 2008, 121, 313-327. [CrossRef]

5. Riaie, S.; Saadatian, M.; Aghaie, M.; Alizadeh, M.; Hajitaghiloo, R. Application salicylic acid and aloevera gel as edible coating layer to preserving fresh-cut melon slices in cold storage. Int. Food Res. J. 2017, 24, 2456-2459.

6. Koh, P.C.; Noranizan, M.A.; Karim, R.; Nur Hanani, Z.A.; Lasik-Kurdyś, M. Combination of alginate coating and repetitive pulsed light for shelf life extension of fresh-cut cantaloupe (Cucumis melo L. reticulatus cv. Glamour). J. Food Process. Preserv. 2018, 42, e13786. [CrossRef]

7. Kasim, R.; Kasim, M.U. Biochemical and color changes of fresh-cut melon (Cucumis melo L. cv. Galia) treated with UV-C. Food Sci. Technol. 2014, 34, 547-551. [CrossRef]

8. Martiñon, M.E.; Moreira, R.G.; Castell-Perez, M.E.; Gomes, C. Development of a multilayered antimicrobial edible coating for shelf life extension of fresh-cut cantaloupe (Cucumis melo L.) stored at $4{ }^{\circ} \mathrm{C}$. LWT-Food Sci. Technol. 2014, 56, 341-350. [CrossRef]

9. Chong, J.X.; Lai, S.; Yang, H. Chitosan combined with calcium chloride impacts fresh-cut honeydew melon by stabilising nanostructures of sodium-carbonate-soluble pectin. Food Control. 2015, 53, 195-205. [CrossRef]

10. Ortiz-Duarte, G.; Pérez-Cabrera, L.E.; Artés-Hernández, F.; Martínez-Hernández, G.B. Ag-chitosan nanocomposites in edible coatings affect the quality of fresh-cut melon. Postharvest Biol. Technol. 2019, 147, 174-184. [CrossRef]

11. Amaro, A.L.; Fundo, J.F.; Oliveira, A.; Beaulieu, J.C.; Fernández-Trujillo, J.P.; Almeida, D.P.F. 1-Methylcyclopropene effects on temporal changes of aroma volatiles and phytochemicals of fresh-cut cantaloupe. J. Sci. Food Agric. 2013, 93, 828-837. [CrossRef]

12. Waqas, A.; Butt, M.S. Application of biodegradable coatings to improve quality and shelf life of minimally processed melon dices. Pakistan J. Food Sci. 2014, 24, 82-90.

13. Moreira, S.P.; De Carvalho, W.M.; Alexandrino, A.C.; De Paula, H.C.B.; Rodrigues, M.d.C.P.; De Figueiredo, R.W.; Maia, G.A.; De Figueiredo, E.M.A.T.; Brasil, I.M. Freshness retention of minimally processed melon using different packages and multilayered edible coating containing microencapsulated essential oil. Int. J. Food Sci. Technol. 2014, 49, 2192-2203. [CrossRef]

14. Poverenov, E.; Danino, S.; Horev, B.; Granit, R.; Vinokur, Y.; Rodov, V. Layer-by-Layer electrostatic deposition of edible coating on fresh cut melon model: Anticipated and unexpected effects of alginate-chitosan combination. Food Bioprocess Technol. 2014, 7, 1424-1432. [CrossRef]

15. Oms-Oliu, G.; Soliva-Fortuny, R.; Martin-Belloso, O. Effect of ripeness on the shelf life of fresh-cut melon preserved by modified atmosphere packaging. Eur. Food Res. Technol. 2007, 225, 301-311. [CrossRef] 
16. Selma, M.V.; Ibáñez, A.M.; Allende, A.; Cantwell, M.; Suslow, T. Effect of gaseous ozone and hot water on microbial and sensory quality of cantaloupe and potential transference of Escherichia coli O157:H7 during cutting. Food Microbiol. 2008, 25, 162-168. [CrossRef]

17. Lamikanra, O.; Kueneman, D.; Ukuku, D.; Bett-Garber, K.L. Effect of processing under ultraviolet light on the shelf life of fresh-cut cantaloupe melon. J. Food Sci. 2005, 70, 534-539. [CrossRef]

18. Manzocco, L.; Da Pieve, S.; Maifreni, M. Impact of UV-C light on safety and quality of fresh-cut melon. Innov. Food Sci. Emerg. Technol. 2011, 12, 13-17. [CrossRef]

19. Wang, Z.; Ma, Y.; Zhao, G.; Liao, X.; Chen, F.; Wu, J.; Chen, J.; Hu, X. Influence of gamma irradiation on enzyme, microorganism, and flavor of cantaloupe (Cucumis melo L.) juice. J. Food Sci. 2006, 71, 215-220. [CrossRef]

20. Abdalrazeq, M.; Giosafatto, C.V.L.; Esposito, M.; Fenderico, M.; Di Pierro, P.; Porta, R. Glycerol-plasticized films obtained from whey proteins denatured at alkaline $\mathrm{pH}$. Coatings 2019, 9, 322. [CrossRef]

21. Sagnelli, D.; Hooshmand, K.; Kemmer, G.C.; Kirkensgaard, J.J.K.; Mortensen, K.; Giosafatto, C.V.L.; Holse, M.; Hebelstrup, K.H.; Bao, J.; Stelte, W.; et al. Cross-linked amylose bio-plastic: A transgenic-based compostable plastic alternative. Int. J. Mol. Sci. 2017, 18, 2075. [CrossRef] [PubMed]

22. Oms-Oliu, G.; Soliva-Fortuny, R.; Martín-Belloso, O. Using polysaccharide-based edible coatings to enhance quality and antioxidant properties of fresh-cut melón. LWT-Food Sci. Technol. 2008, 41, 1862-1870. [CrossRef]

23. Ferrari, C.C.; Sarantopoulos, C.I.G.L.; Carmello-Guerreiro, S.M.; Hubinger, M.D. Effect of osmotic dehydration and pectin edible coatings on quality and shelf life of fresh-cut melon. Food Bioprocess Technol. 2013, 6, 80-91. [CrossRef]

24. Parreidt, T.S.; Schmid, M.; Muller, K. Effect of dipping and vacuum impregnation coating techniques with alginate based coating on physical quality parameters of Cantaloupe melon. J. Food Sci. 2018, 83, 929-936. [CrossRef] [PubMed]

25. Haffez, M.M.; Ragab, M.E.; Abou El-Yazied, A.; Emam, M.S. Effect of chitosan, carboxy methyl cellulose and calcium chloride treatments on quality and storability of fresh cut Cantaloupe. Middle East J. Appl. Sci. 2016, 6, 249-268.

26. Rabea, E.I.; Badawy, M.E.-T.; Stevens, C.V.; Smagghe, G.; Steurbaut, W. Chitosan as antimicrobial agent: Applications and mode of action. Biomacromolecules 2003, 4, 1457-1465. [CrossRef]

27. Brasil, I.M.; Gomes, C.; Puerta-Gomez, A.; Castell-Perez, M.E.; Moreira, R.G. Polysaccharide-based multilayered antimicrobial edible coating enhances quality of fresh-cut papaya. LWT-Food Sci. Technol. 2012, 47, 39-45. [CrossRef]

28. Benítez, S.; Achaerandio, I.; Pujolá, M.; Sepulcre, F. Aloe vera as an alternative to traditional edible coatings used in fresh-cut fruits: A case of study with kiwifruits slices. LWT-Food Sci. Technol. 2015, 61, 184-193. [CrossRef]

29. Fedeniuk, R.W.; Biliaderis, C.G. Composition and physicochemical properties of linseed (Linum usitatissimum L.) mucilage. J. Agric. Food Chem. 1994, 42, 240-247. [CrossRef]

30. Chen, H.-H.; Xu, S.-Y.; Wang, Z. Gelation properties of flaxseed gum. J. Food Eng. 2006, 77, $295-303$. [CrossRef]

31. Mirhosseini, H.; Amid, B.T. A review study on chemical composition and molecular structure of newly plant gum exudates and seed gums. Food Res. Int. 2012, 46, 387-398. [CrossRef]

32. Treviño-Garza, M.Z.; García, S.; Heredia, N.; Alanís-Guzmán, M.G.; Arévalo-Niño, K. Layer-by-layer edible coatings based on mucilages, pullulan and chitosan and its effect on quality and preservation of fresh-cut pineapple (Ananas comosus). Postharvest Biol. Technol. 2017, 128, 63-75. [CrossRef]

33. Soleimani-Rambod, A.; Zomorodi, S.; Naghizadeh Raeisi, S.; Khosrowshahi Asl, A.; Shahidi, S.-A. The effect of xanthan gum and flaxseed mucilage as edible coatings in cheddar cheese during ripening. Coatings 2018, 8, 80. [CrossRef]

34. Sipahi, R.E.; Castell-Perez, M.E.; Moreira, R.G.; Gomes, C.; Castillo, A. Improved multilayered antimicrobial alginate-based edible coating extends the shelf life of fresh-cut watermelon (Citrullus lanatus). LWT-Food Sci. Technol. 2013, 51, 9-15. [CrossRef]

35. Official Methods of Analysis, 13th ed.; AOAC International: Washington, DC, USA, 1990.

36. Suntornsuk, L.; Gritsanapun, W.; Nilkamhank, S.; Paochom, A. Quantitation of vitamin C content in herbal juice using direct titration. J. Pharm. Biomed. Anal. 2002, 28, 849-855. [CrossRef] 
37. Treviño-Garza, M.Z.; García, S.; Flores-González, M.d.S.; Arévalo-Niño, K. Edible active coatings based on pectin, pullulan, and chitosan increase quality and shelf life of strawberries (Fragaria ananassa). J. Food Sci. 2015, 80, 1823-1830. [CrossRef] [PubMed]

38. Vanoli, M.; Grassi, M.; Buccheri, M.; Rizzolo, A. Influence of edible coatings on postharvest physiology and quality of Honeydew melon fruit (Cucumis melo L. inodorus). Adv. Hortic. Sci. 2015, 29, 65-74. [CrossRef]

39. Aguayo, E.; Escalona, V.H.; Artés, F. Metabolic behavior and quality changes of whole and fresh processed melon. J. Food Sci. 2004, 69, 148-155. [CrossRef]

40. Syahidah, K.; Rosnah, S.; Noranizan, M.A.; Zaulia, O.; Anvarjon, A. Quality changes of fresh cut cantaloupe (Cucumis melo L. var Reticulatus cv. Glamour) in different types of polypropylene packaging. Int. Food Res. J. 2015, 22, 753-760.

41. Zambrano-Zaragoza, M.L.; Quintanar-Guerrero, D.; Del Real, A.; Piñon-Segundo, E.; Zambrano-Zaragoza, J.F. The release kinetics of $\beta$-carotene nanocapsules/xanthan gum coatings and quality changes in fresh-cut melon (cantaloupe). Carbohydr. Polym. 2017, 157, 1874-1882. [CrossRef]

42. Lamikanra, O.; Chen, J.C.; Banks, D.; Hunter, P.A. Biochemical and microbial changes during the storage of minimally processed Cantaloupe. J. Agric. Food Chem. 2000, 48, 5955-5961. [CrossRef] [PubMed]

43. Guo, Q.; Cheng, L.; Wang, J.; Che, F.; Zhang, P.; Wu, B. Quality characteristics of fresh-cut 'Hami' melon treated with 1-methylcyclopropene. Afr. J. Biotechnol. 2011, 10, 18200-18209. [CrossRef]

(C) 2019 by the authors. Licensee MDPI, Basel, Switzerland. This article is an open access article distributed under the terms and conditions of the Creative Commons Attribution (CC BY) license (http://creativecommons.org/licenses/by/4.0/). 